\title{
Direct Intratumoral Injection of an Adenovirus Expressing Interleukin-12 Induces Regression and Long-Lasting Immunity That Is Associated with Highly Localized Expression of Interleukin-12
}

\author{
J.L. BRAMSON, ${ }^{1,2}$ M. HITT, ${ }^{1}$ C.L. ADDISON, ${ }^{1}$ W.J. MULLER, ${ }^{2}{ }^{\text {J. GAULDIE, }}{ }^{2}$ and F.L. GRAHAM ${ }^{1,2}$
}

\begin{abstract}
Mice bearing breast tumors were treated with a single dose of an adenovirus expressing interleukin-12 (AdmIL12.1) injected intratumorally, which produced regressions in greater than $75 \%$ of the treated tumors; approximately one-third of the animals remained tumor free. Complete regression was associated with immunity to secondary challenge with fresh tumor cells. Analysis of local cytokine expression demonstrated maximum expression of $\mathrm{IL}-12$ within the tumor between 24 and $72 \mathrm{hr}$ post-injection, reaching 600-800 $\mathrm{ng}$ per tumor, with elevated local levels of IL-12 detectable for at least 9 days. This expression was highly localized as serum IL-12 peaked at 40-60 ng/ml at $24 \mathrm{hr}$ and was less than $10 \mathrm{ng} / \mathrm{ml}$ from day 3 onward. Interferon- $\gamma$ (IFN- $\gamma$ ) concentrations were markedly increased within the tumor following AdmIL-12.1 administration, demonstrating that IL-12 was acting locally. Tumor-draining lymph node cells spontaneously produced IFN$\gamma$ following AdmIL-12.1 treatment, suggesting these cells were activated by IL-12. These data demonstrate that AdmIL-12.1 can be used to deliver very high levels of localized cytokine production. Moreover, we have confirmed that the IL-12 produced from our vector actually affects the local cytokine environment of the tumor and activates responder cells present within the tumor.
\end{abstract}

\section{OVERVIEW SUMMARY}

The systemic toxicities associated with many recombinant cytokines can limit their use in vivo for cancer immunotherapy. We have directly infected murine tumors in vivo with an adenoviral vector expressing interleukin-12 (IL-12) to generate high intratumoral cytokine levels. This treatment lead to tumor regression and long-term immunity in those animals whose tumors regressed completely. The expression of IL-12 was localized primarily to the tumor, resulted in an increase in interferon- $\gamma$ (IFN- $\gamma$ ) levels within the tumor, and promoted IFN- $\gamma$ expression in the cells from the draining lymph node. These data demonstrate that adenoviral vectors can be used to produce very high levels of cytokine locally. Moreover, we have confirmed that intratumoral IL-12 production can alter the local cytokine environment of the tumor and activate responder cells present within the tumor.

\section{INTRODUCTION}

MAJOR LIMTATION in the effective treatment of cancer is
the presence of residual disease and metastases follow-
ing standard treatment protocols involving surgical resection,
chemotherapy or radiation. Many novel therapies are being
developed in an attempt to overcome this hurdle, including
immunologic and genetic approaches. Immunologic interven-
tion represents one of the more promising strategies, because
the immune system is uniquely suited to seek out and destroy
residual tumor cells that may otherwise persist, resulting in a
recurrence of the malignancy. The development of tumor im-
munity is inhibited in many ways by the malignant cells dur-
ing tumor progression (Abbas et al., 1991). One mechanism
by which these barriers may be overcome is through stimula-
tion of anergic T cells by the addition of exogenous cytokines.
Systemic administration of cytokines can produce substantial
antitumor activity but the severe toxicity associated with this

Departments of ${ }^{1}$ Biology and ${ }^{2}$ Pathology, McMaster University, Hamilton, Ontario L8S 4K1. 
approach at effective doses is cause for concern. Several methods have been developed to deliver the cytokine directly to the tumor environment so that associated systemic toxicities can be reduced (Pardoll, 1995). The approach we have chosen involves direct genetic modification of the tumors in vivo using adenovirus (Ad) vectors to deliver cytokine genes, making the tumor cell a source of cytokine production. Ad vectors offers many attractive features for in vivo gene transfer: (i) they are highly infectious, (ii) they can be easily grown to high titers, (iii) they can be rendered replication incompetent by deletion of the $\mathrm{E} 1$ region, and (iv) they have a cloning capacity of approximately $8 \mathrm{~kb}$, which is ample for insertion of any of the cloned cytokine cDNAs (Hitt et al., 1994; Bramson et al., 1995). E1-deleted first-generation Ad vectors have been shown to be quite immunogenic (Yang et al., 1994), which, although a disadvantage for some gene therapies, may be beneficial for immunotherapy because this will limit the duration of cytokine expression and could provide adjuvant stimulus for the development of antitumor immunity. These viruses have been used by several groups, including our own, to transfer successfully a variety of genes into tumors in vivo (Bramson et al., 1995).

Interleukin-12 (IL-12) is a multifunctional cytokine that has attracted much attention for its antitumor properties. IL-12 has been shown to enhance the cytolytic activity of natural killer (NK) and cytotoxic T lymphocyte (CTL) cells, is a very strong inducer of interferon- $\gamma(\mathrm{IFN}-\gamma)$, and appears to be a major determinant in the development of a $\mathrm{T}_{\mathrm{h}} 1 / \mathrm{TC} 1$ response (cellmediated immunity) (reviewed by Hendrzak and Brunda, 1995). In mouse models, systemic treatment using recombinant IL-12 revealed no serious side effects at doses that lead to significant antitumor responses (Brunda et al., 1993; Nastala et al., 1994; Zou et al., 1995; Tannenbaum et al., 1996). Systemic administration of IL-12 in mice and squirrel monkeys can result in a reversible, dose-dependent suppression of peripheral blood counts (anemia, leukopenia, thrombocytopenia) and splenomegaly associated with enhanced splenic extramedullary hematopoiesis (Gatley et al., 1994; Sarmiento et al., 1994; Tare et al., 1995). Phase I trials of systemic IL-12 treatment in renal cell carcinoma have been completed and although phase II trials were temporarily suspended due to apparent toxicity, the toxicity has been overcome and the trials have been resumed (Cohen, 1995). As mentioned above, direct delivery of IL-12 to the tumor mass should reduce associated systemic effects. A number of gene transfer vectors have been developed that express this cytokine, including vectors based on Ad, retroviruses, and vaccinia virus (Bramson et al., 1996; Zitvogel et al., 1994; Meko et al., 1995).

In the studies described here, we have investigated the outcome of direct injection of the Ad expressing $\mathrm{IL}-12$ (AdmIL12.1) into subcutaneous murine tumors using a transgenic mouse model of metastatic breast cancer (Guy et al., 1992). We show that a single dose of AdmIL-12.1 can effectively induce tumor regression, resulting in subsequent immunity to rechallenge with fresh tumor cells. Moreover, the expression of IL-12 within the tumor appears to be localized and causes local increases in IFN- $\gamma$ production and activation of effector cells draining from the tumor.

\section{MATERIALS AND METHODS}

\section{Animals and reagents}

Six- to 8-week-old FVB/n female mice were obtained from Taconic Laboratories and housed in a specific pathogen-free facility until use. Recombinant murine $\mathrm{IL}-12$ was purchased from Pharmingen and murine IFN- $\gamma$ was obtained from Boehringer Mannheim. Rabbit anti-IL12 and anti-IFN- $\gamma$ polyserum were kindly provided by Steven L. Kunkel (University of Michigan, Ann Arbor). The anti-IL12 serum recognizes p35, p40, and p75 by Western blot and neutralizes recombinant murine $\mathrm{IL}-12$ in a bioassay in vitro (data not shown). These antisera did not cross-react with each other or with a battery of other murine cytokines that included tumor necrosis factor (TNF), interleukin-1 $\alpha \beta$ (IL-1 $\alpha \beta$ ), IL-2, IL-4, IL-5, IL-10, monocyte chemotactic peptide-1 (MCP-1), and macrophage inflammatory peptide-1 $\alpha$ (MIP-1 $\alpha$ ) (Chensue et al., 1995). All cell culture media and reagents were obtained from GIBCO and tissue culture dishes and ELISA plates were from NUNC.

\section{Adenoviral vectors}

Viruses were propagated on 293 cells (Graham et al., 1977) and purified by cesium chloride gradient centrifugation as described by Hitt et al. (1994). Construction and characterization of an Ad vector expressing murine IL-12, AdmIL12.1, has been described previously (Bramson et al., 1996). The Ad5-based recombinant system used to produce these vectors allows for the insertion of expression cassettes in either the E1 or E3 region of Ad5 (Bett et al., 1994). The expression cassette for the p35 subunit of IL-12 is in the E1 region of AdmIL12.1 and the IL12 p40 subunit cassette is in the E3 region. Expression of each IL-12 cDNA is driven by the human cytomegalovirus (HCMV) immediate early gene promoter and terminated by the polyadenylation signal of SV40, and transcription is in the same direction as the E1 and E3 transcription units they replace. The control adenovirus, $d l 70-3$, is a mutant of Ad5 deleted in E1 and having a deletion/substitution in E3 (Bett et al., 1994).

\section{Tumor studies}

The tumor model used in this study is based on a transgenic strain described by Guy et al. (1992) that harbors the polyoma middle $\mathrm{T}$ antigen (PyMT) gene under the control of the mouse mammary tumor virus long terminal repeat (LTR). Female transgenic mice undergo spontaneous transformation of the mammary epithelium by 8-10 weeks of age. These tumors can be excised and transplanted ectopically to syngeneic FVB/n mice (e.g., by subcutaneous injection into the hind flanks), where they will induce tumors and grow indefinitely (typically the animals must be sacrificed at 40-60 days). Briefly, tumors were established in syngeneic mice as follows: tumors were excised from euthanized transgenic mice and a unicellular suspension was prepared as described previously (Addison $e t$ al., 1995a). An aliquot of $10^{6}$ tumor cells was injected subcutaneously in the right hind flank of normal $\mathrm{FVB} / \mathrm{n}$ mice. Approximately 21 days later, visible tumors had developed in all the recipients and at this time the mice were injected intratumorally with the appropriate concentration of virus in a volume of $50 \mu \mathrm{l}$. In experiments where anti-IL12 antibody was 
used, the antiserum was delivered $4 \mathrm{hr}$ prior to virus injection on day 1 and again on days 3 and 5 as described by Chensue et al. (1995) (the antibody half-life in serum is $50 \mathrm{hr}$ ). Tumors were measured biweekly using calipers and the tumor volume as calculated from the longest diameter and average width, assuming a prolate spheroid. The animals were sacrificed when the longest diameter was greater than $20 \mathrm{~mm}$ or when any two measurements were greater than $10 \mathrm{~mm}$.

\section{Cytokine ELISA}

At specified times, blood was drawn from the retro-orbital sinus of randomly selected mice and tumors were removed from euthanized mice and snap-frozen in liquid nitrogen. Frozen tissue was homogenized in PBS $(0.5-1 \mathrm{ml}$, depending on tumor size) containing $100 \mu M$ phenylmethylsulfonyl fluoride (PMSF) and $10 \mu \mathrm{g} / \mathrm{ml}$ aprotonin. The homogenate was then sonicated twice for $10 \mathrm{sec}$ and cleared by centrifugation in a microfuge for $5 \mathrm{~min}$ at room temperature. Animal sera and tumor homogenates were stored at $-20^{\circ} \mathrm{C}$.

The IL-12 and IFN- $\gamma$ ELISAs were performed as described previously (Chensue et al., 1995). Briefly, flat-bottomed 96well microtited plates (NUNC Maxisorp) were coated overnight with polyclonal rabbit antiserum $(18 \mu \mathrm{g} / \mathrm{ml}$ anti-IL- $12 ; 10$ $\mu \mathrm{g} / \mathrm{ml}$ anti-IFN- $\gamma$ ) at $4^{\circ} \mathrm{C}$. The day of the assay, the wells were washed three times and nonspecific binding was blocked using $2 \%$ bovine serum albumin in PBS for $90 \mathrm{~min}$ at $37^{\circ} \mathrm{C}$. The blocking buffer was removed and the wells washed three times. The samples were then added and incubated at $37^{\circ} \mathrm{C}$ for $60 \mathrm{~min}$. The wells were washed five times and biotinylated antibody was added ( $18 \mu \mathrm{g} / \mathrm{ml}$ anti-IL-12; $4 \mu \mathrm{g} / \mathrm{ml}$ anti-IFN- $\gamma$ ) followed by a $45-\mathrm{min}$ incubation at $37^{\circ} \mathrm{C}$. The plates were washed three times and avidin-conjugated horseradish peroxidase (Bio-Rad) was added and incubated $30 \mathrm{~min}$ at $37^{\circ} \mathrm{C}$. The plates were again washed three times, the peroxidase substrate OPD (Pierce) was added, and the reaction was terminated after $5 \mathrm{~min}$ by the addition of $3 \mathrm{~N} \mathrm{H}_{2} \mathrm{SO}_{4}$. Recombinant proteins were included in each analysis and the ELISAs were consistently sensitive to 50 $\mathrm{pg} / \mathrm{ml}$.

\section{Statistical analysis}

All data are expressed as mean \pm SEM and compared using an unpaired, two-tailed Student's $t$-test. The statistics were calculated using Statview $512+$ on a Macintosh IIci (Abacus Concepts, Inc., Berkeley, CA).

\section{RESULTS}

\section{Antitumoral activity of AdmIL-12.1}

Previous studies using Ad vectors expressing IL-2 and IL-4 to treat PyMT tumors demonstrated that direct injection of $5 \times$ $10^{8}$ plaque-forming units (pfu) was most efficacious (Addison et al., 1995a,b). Therefore, we used this dose of AdmIL-12.1 initially and compared it to the effects of a control virus, $d l 70$ 3, which lacks the E1 region making it replication deficient. The tumors were injected with virus on day 21 following implantation of tumor cells on the right hind flank and animals
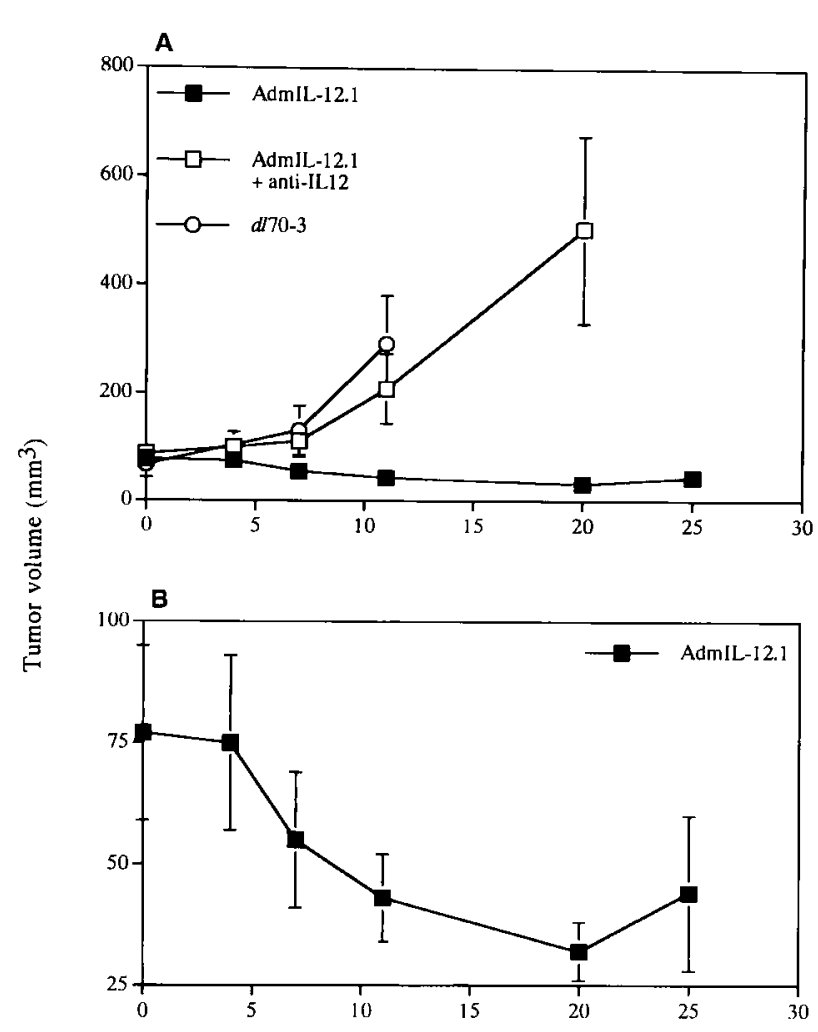

Days following intratumoral injection

FIG. 1. Induction of tumor regression following intratumoral injection with AdmIL-12.1. Tumors were treated with either AdmIL-12.1 or $d l 70-3$ as described in the Materials and Methods. A and B represent the same experiment, but the data in $B$ have been replotted to display the results following AdmIL12.1 treatment in greater detail. (O) Control virustreated samples; $(\square)$ animals treated with AdmIL12.1; ( $\square$ ) animals treated with AdmIL12.1 concomittantly with anti-IL12 polyserum.

were subsequently monitored on a regular basis to follow tumor progression. Injection of the control virus did not prevent tumor growth (Addison et al., 1995a) (Fig. 1A, open circles). In contrast, AdmIL-12.1 treatment resulted in substantial reduction in tumor volume (Fig. 1B, closed squares). In the experiment shown in Fig. 1, the mean tumor volume at the time of injection for the AdmIL-12.1 treated group was $76.8 \pm 17.9$ $\mathrm{mm}^{3}$ and by day 20 the mean volume had diminished to $32.2 \pm$ $6.4 \mathrm{~mm}^{3}(p=0.573)$. This effect was cytokine dependent because when neutralizing antibody to IL-12 was delivered at the same time as the virus, the antitumor effects were abrogated (Fig. 1A, open squares). Normal rabbit serum had no effect on the outcome of AdmIL-12.1 therapy (data not shown). Treatment with AdmIL-12.1 produced regression in 28/36 tumors $(78 \%)$, and $11 / 36(32 \%)$ of the animals have remained tumor free for the duration of the experiment, and in some cases greater than 1 year (Fig. 2; Table 1). In the remaining 8 animals, five tumors remained static for a period of 2-3 weeks, at which point they resume growth, whereas the other three tumors displayed no response. The results from six experiments (36 animals treated with AdmIL-12.1) are summarized in Table 


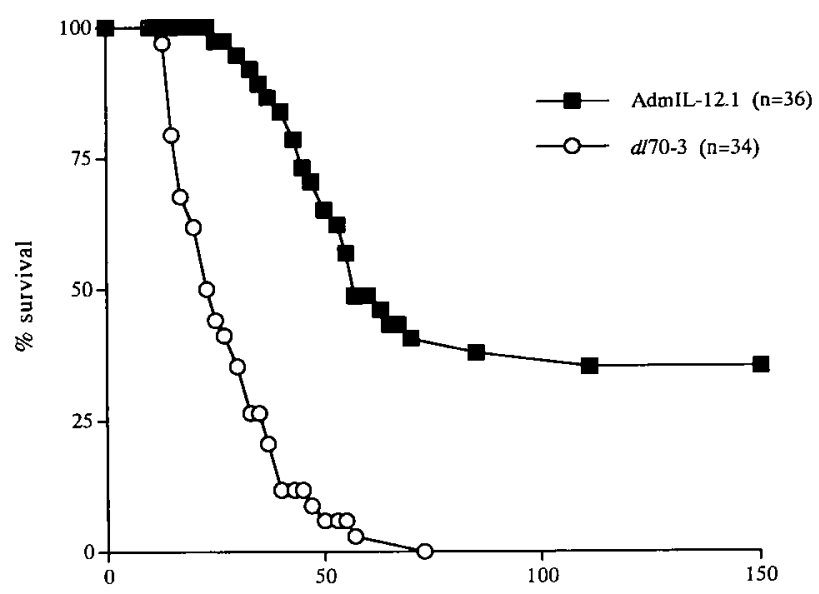

Day following intratumoral injection

FIG. 2. Long-term survival following treatment with AdmIL12.1. The survival of the experimental animals is plotted as a function of time. (O) dl70-3-treated tumors $(n=34)$; $(\square)$ AdmIL12.1-treated tumors $(n=36)$.

1. The overall response rate was $92 \%$, clearly demonstrating the potency of this therapy. None of the animals in the study treated with $d l 70-3(n=34)$ showed evidence of a response. Even among those animals whose tumors did not completely regress, mean survival following virus injection was increased approximately two-fold $[28 \pm 3$ days $(d l 70-3)$ vs. $52 \pm 4$ days (AdmIL-12.1); $p=0.0001$ ]. We observed similar results using $2.5 \times 10^{8}$ pfu AdmL-12.1 per treatment, but increasing the viral load to $2 \times 10^{9} \mathrm{pfu}$ AdmIL-12.1 per tumor did not improve the outcome (data not shown). We also found that using as low as $5 \times 10^{7}$ pfu AdmIL-12.1, we could achieve complete regression in 1 of 4 treated animals. Thus, the AdmIL-12.1 treatment seems to have a wide window of activity. We did not observe any gross side effects of the treatment, although 1 animal out of 37 died after treatment with AdmIL-12.1. It was not clear, however, that the death was cytokine related.

Table 1. Summary of Responses Following INTRATUMORAL INJECTION OF ADMIL-12.1 ${ }^{\mathrm{a}}$

\begin{tabular}{lccc}
\hline $\begin{array}{l}\text { Complete } \\
\text { regression }\end{array}$ & $\begin{array}{c}\text { Partial } \\
\text { regression }\end{array}$ & $\begin{array}{c}\text { Growth } \\
\text { delay }^{\mathrm{d}}\end{array}$ & $\begin{array}{c}\text { No } \\
\text { response }\end{array}$ \\
\hline 11 & 17 & 5 & 3
\end{tabular}

Complete response $=11 / 36(31 \%)$; overall response $=33 / 36$ (92\%).

${ }^{a}$ Animals with established tumors were treated intratumorally with $5 \times 10^{8}$ pfu AdmIL-12.1 and the resultant changes in tumor volume were measured regularly. The table summarizes the results of six experiments involving 3-9 animals each.

bTumors regressed completely and did not return for at least 2 months.

'Tumors initially regressed to less than $50 \%$ of the initial size but were not eliminated and eventually returned.

${ }^{\mathrm{d}}$ Tumors displayed no change in tumor volume for at least 2 weeks following treatment.

\section{Tumor regression is associated with long-term immunity}

One of the objectives of cytokine immunotherapy is to induce immunity against the treated tumor and, thus, protect against recurrence and metastatic spread. To test whether AdmIL12.1 treatment could produce long-term immunity, the 11 animals that had been cured were rechallenged with fresh tumor cells on the opposite flank 2-3 months following disappearance of the primary tumor. Ten of the 11 animals were resistant to rechallenge, whereas all control mice developed tumors at the usual time (approximately 2-3 weeks post-challenge). Only 1 animal was not completely resistant to rechallenge; however this mouse did demonstrate a delay in tumor appearance by greater than 3 weeks compared to the controls.

\section{Expression of IL-12 following intratumoral injection is localized to the tumor}

To determine the extent of localization of IL-12 within the tumor mass, a time course of $\mathrm{IL}-12$ expression following intratumoral injection of either AdmIL12.1 or $d l 70-3$ was performed across a period of 2 weeks. Animals were injected with $5 \times 10^{8}$ pfu of either AdmIL-12.1 or $d l 70-3$ and 2 animals from each group were sacrificed at various times to quantify the IL12 levels in the serum and within the tumor (Fig. 3). We compared intratumoral expression of IL-12 to serum IL-12 in Fig. 3 a by approximating total IL-12 in the serum, assuming a total blood volume of $2 \mathrm{ml}$ per animal, which would yield $1 \mathrm{ml}$ of serum. The peak expression of $\mathrm{IL}-12$ reached approximately $800 \mathrm{ng}$ within the tumor mass, yet never exceeded $60 \mathrm{ng} / \mathrm{ml}$ in the serum. Moreover, IL-12 expression in the tumor peaked between 24 and $72 \mathrm{hr}$ whereas serum IL-12 was maximal at 24 hr post injection $(60 \mathrm{ng} / \mathrm{ml})$ and by $72 \mathrm{hr}$ serum IL-12 was reduced to less than $10 \mathrm{ng} / \mathrm{ml}$. Thus, $\mathrm{IL}-12$ expression appeared to be primarily localized to the tumor with little dissemination in the circulation. Both intratumoral and serum IL-12 were detectable by ELISA throughout the 14-day experiment. IL-12 expression was also slightly elevated in the $d l 70-3$-treated tumors (Fig. 3b), most likely due to the host response to Ad infection. Over the course of the experiment, the tumors in the control group increased in size, whereas those of the AdmIL-12.1 group began to regress. Therefore, the data in Fig. $3 b$ were normalized to tumor mass to take into account the changes in tumor volume

\section{Expression of $I L-12$ within the tumor causes increases in local IFN- $\gamma$ production}

Induction of IFN- $\gamma$ production is a well-defined characteristic of IL-12 treatment and it has been shown that IFN- $\gamma$ is required for at least part of the antitumor properties of IL-12 (Nastala et al., 1994; Brunda et al., 1995; Zou et al., 1995). We have examined the expression of IFN- $\gamma$ within the tumor as an indicator of local changes within the cytokine environment caused by AdmIL-12.1. In the tumors injected with AdmIL12.1 , we observed a very rapid increase in the local concentration of IFN- $\gamma$ (Fig. 4; the data was normalized to tumor volume as described in the previous paragraph). It is notable that IFN- $\gamma$ production reached maximum levels from days 6 to 9 , 

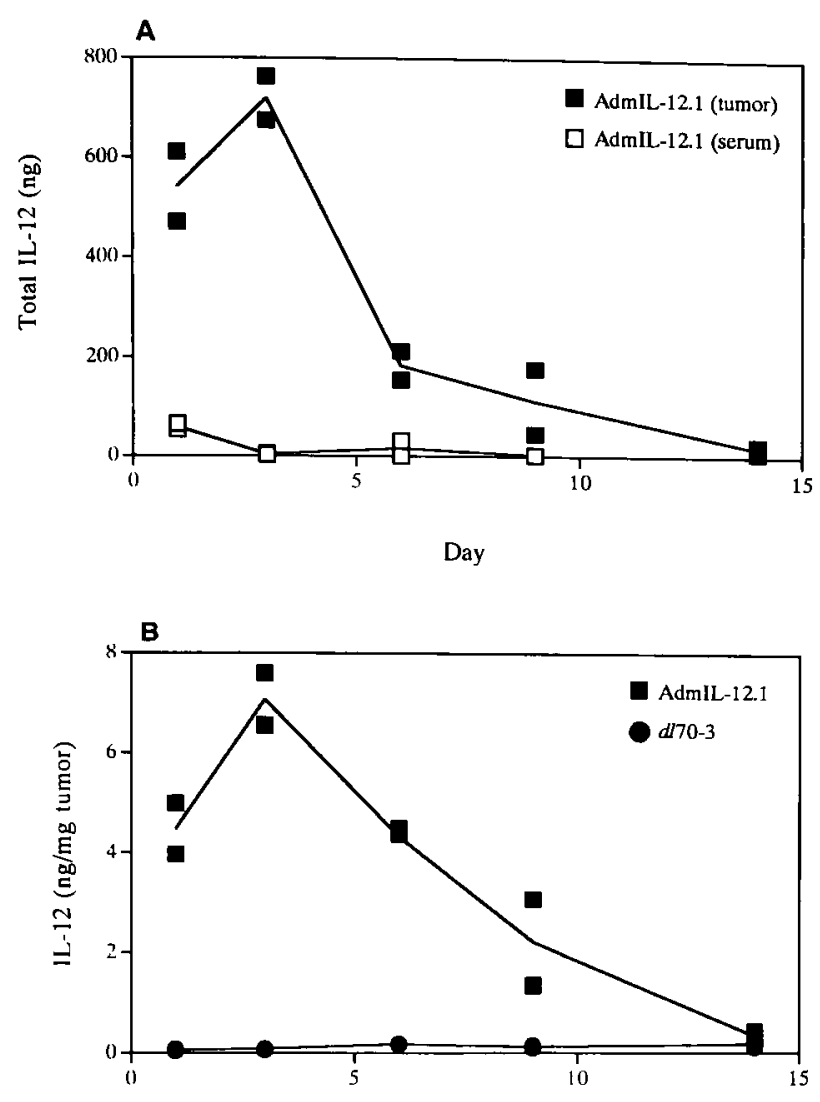

Day

FIG. 3. Comparison of intratumoral expression of IL-12 and serum IL-12. Following intratumoral treatment with AdmIL12.1 $(\boldsymbol{\square}, \square)$ or $d l 70-3(\bullet), 2$ animals were sacrificed on days $1,3,6,9$, and 14 and the $I L-12$ concentration was measured in both their tumors and serum. IL-12 expression in tumor homogenates and sera was measured using an ELISA as described in Materials and Methods. These results represent one of two experiments with similar results. A. Total IL-12 in the tumor (a) following intratumoral injection of $5 \times 10^{8} \mathrm{pfu}$ AdmIL12.1 is compared to total IL-12 in the serum ( $\square$ ). Total serum IL-12 was approximated by assuming a total blood volume per mouse of $2 \mathrm{ml}$ yielding $1 \mathrm{ml}$ of serum. B. Intratumoral expression of $\mathrm{IL}-12$ following injection of $5 \times 10^{8} \mathrm{pfu}$ AdmIL12.1 (ם) or $d l 70-3(\bigcirc)$. The IL-12 expression was normalized to the tumor mass as an indication of local "concentration."

after the IL-12 expression had begun to decline (compare Fig. 4 vs. Fig. 3b). The levels of IFN- $\gamma$ were three- to five-fold higher in the AdmIL-12.1-treated tumors than the control group at day 6 . The control virus also induced an increase in IFN- $\gamma$ expression, but this did not reach the same level as the AdmIL-12.1 treatment and was probably a consequence of an antiviral response.

\section{AdmIL-12.1 treatment induces IFN- $\gamma$ expression in draining lymph node cells}

To demonstrate a direct effect of AdmIL-12.1 treatment on the effector cells present within the tumor, we removed the

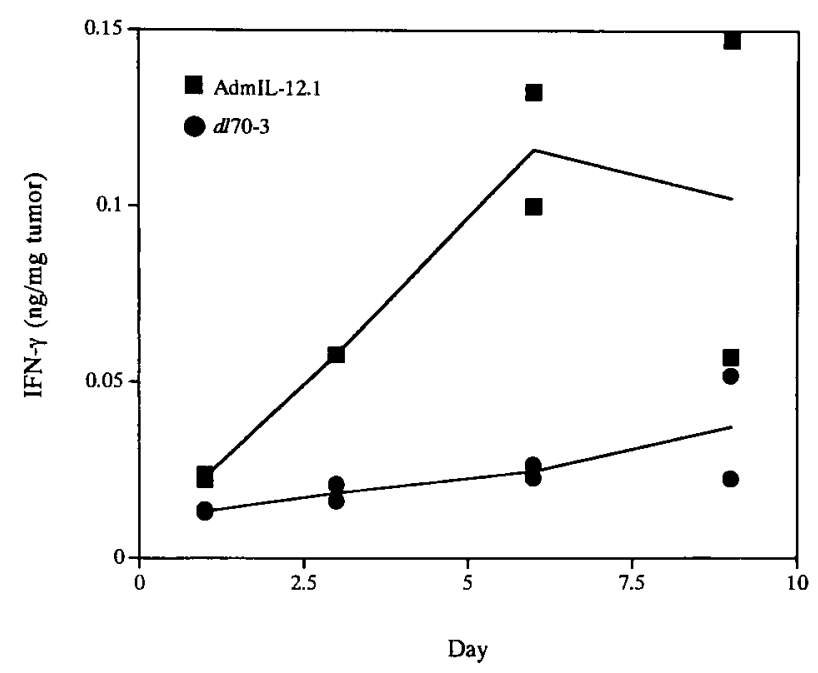

FIG. 4. Increased local IFN- $\gamma$ expression following treatment with AdmIL12.1. The AdmIL12.1-treated tumors ( $\mathbf{0}$; two samples per day) were screened for the expression of IFN- $\gamma$ and compared to $d l 70$-3-treated tumors (O; two samples per day). The IFN- $\gamma$ expression was measured in tumor homogenates using an ELISA as described in Material and Methods. IFN- $\gamma$ expression was then normalized to the mass of the tumor as an indication of "concentration."

lymph nodes draining the tumors (TDLN) and determined the IFN- $\gamma$ production from the TDLN cells after $24 \mathrm{hr}$ in culture (Fig. 5). The TDLN cells from all the AdmIL-12.1-treated animals secreted high levels of IFN- $\gamma$, whereas only half of the lymph nodes from the $d l 70-3$-treated animals expressed any detectable IFN- $\gamma$. Taken together, these data indicate that intratumoral injection of AdmIL-12.1 produces tumor regression that is associated with local changes in the cytokine environment of the tumor.

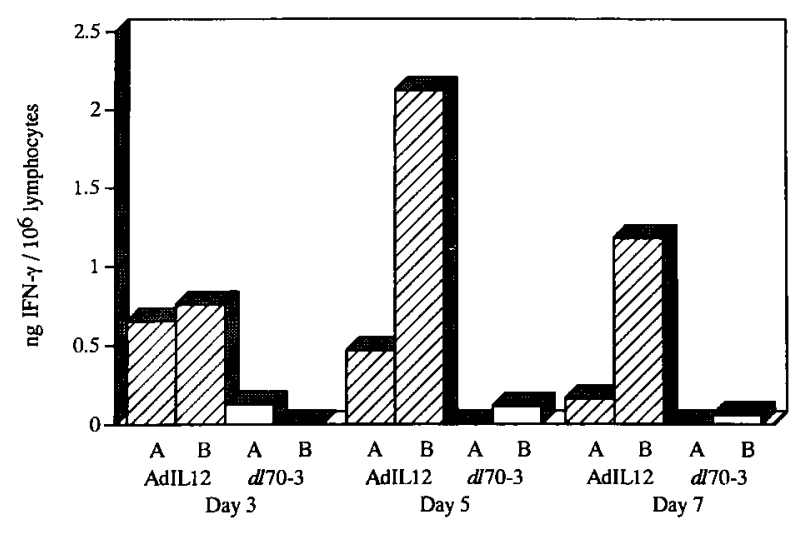

FIG. 5. IFN- $\gamma$ production by draining lymph node cells. Cells were harvested from the draining lymph nodes of mice (two per day) treated with $d l 70-3$ (open bars) or AdmIL12.1 (crosshatched bars). The cells were incubated for $24 \mathrm{hr}$ in vitro at a density of $10^{6} \mathrm{cells} / \mathrm{ml}$, and the IFN- $\gamma$ in the medium was determined by ELISA. IFN- $\gamma$ production in the culture supernatants was normalized to $10^{6}$ cells. 


\section{DISCUSSION}

Systemic toxicities associated with immunotherapy might be overcome if cytokine expression were localized to the tumor site. Our approach to this problem is to use Ad vectors to modify tumor cells genetically with cytokine cDNAs so that the tumor cells can supply the cytokine of interest in a paracrine fashion to the antitumor responder cells present within the tumor. Using an Ad vector expressing mIL-12, we have shown that a single injection of the virus can lead to complete tumor regression in $>30 \%$ of the cases with an overall response rate of $>90 \%$. This response was similar to that observed with other Ad vectors expressing IL-2 or IL-4 (Addison et al., 1995a,b; Cordier et al., 1995), whereas vectors expressing IL-5 or IL-6 had little or no effect (T. Braciak, unpublished data). In contrast to the AdmIL-12.1 treatment, the IL-2- and IL-4-expressing vectors exhibited toxicity at doses needed to induce regression (Addison et al., 1995a, 1995b), whereas there were no obvious toxic side effects associated with AdmIL-12.1 treatment. We have observed one death following treatment of 37 animals with AdmIL-12.1, but it is not clear that the vector alone was responsible for that death. We found that similar results could be achieved using $2.5 \times 10^{8}$ and $5 \times 10^{8}$ pfu AdmIL-12.1 and that complete regression could be achieved in 1 out of 4 animals using as little as $5 \times 10^{7}$ pfu AdmIL12.1 (J. Bramson, unpublished data). Thus, it seemed that AdmIL-12.1 has a relatively broad window of therapeutic activity. Increasing the viral load to $2 \times 10^{9} \mathrm{pfu}$ did not improve the outcome, so it does not appear that the failure to induce complete regression can be explained by the quantity of AdmIL-12.1 being limiting, although the duration of expression may play a factor.

Zitvogel et al. (1995) have used fibroblasts transduced with a retroviral vector expressing murine IL-12 to successfully treat pre-established tumors. An antitumor response was observed whether the fibroblasts were implanted at the tumor site or at a distant site, indicating that circulating levels of IL-12 played an important role in the antitumor activity of IL-12 in that model. The authors do state that the "antitumor effects were observed more rapidly" when the cells were injected at the tumor site, suggesting that local expression was more effective. It is not clear in our model what role circulating IL-12 plays in the antitumor response and it is quite possible that the low level of serum IL-12 we have detected may be beneficial in our therapy. The advantage of AdmIL-12.1 over the retrovirus is that the tumor cells could be transduced directly, without the need to culture autologous fibroblasts, although it may be possible that retroviruses can also be used in vivo. A vaccinia virus expressing mIL-12 has been shown to suppress tumor growth (Meko et al., 1995) but the effect of this vector in a model of pre-established tumors has not yet been reported.

In the present study, 10 of 11 animals that were rechallenged following regression of the initial tumor demonstrated longterm immunity, whereas 1 animal succumbed to the challenge. Nastala et al. (1994) also found that a fraction of animals cured of tumors by IL-12 did not possess long-term immunity, suggesting that the antitumoral effects of IL-12 may also include non-T cell-mediated events. Voest et al. (1995) have demonstrated that IL-12 exhibits antiangiogenic activities that can account for some antitumor activity. It is also interesting to note that at least 2 animals have maintained antitumor immunity for as long as 8 months following tumor regression. However, we have also observed 1 animal that was immune 3 months after treatment but lost this immunity by 8 months. Although these numbers are small, this observation indicates that immunity can wane over the long term and we must consider ways to extend this immunity because the latency of residual tumor cells within the body is unknown. One possible way of maintaining longterm immunity is by boosting the host with irradiated tumor cells, periodically providing a regular source of tumor antigen.

Very high levels of $\mathrm{IL}-12$ (400-800 ng) within the tumor could be detected within the first 3 days following AdmIL-12.1 administration. Interestingly, these levels were similar between the various tumor samples, indicating that viral delivery to the tumor was relatively consistent. Although it is difficult to determine what fraction of the IL-12 produced within the tumor is intracellular, we do know that in vitro, tumor cells infected with AdmIL-12.1 at an moi of 30 will secrete 5,000 ng of bioactive IL-12/10 6 cells per $24 \mathrm{hr}$ (Bramson et al., 1996). Therefore, we would expect that the tumors would express similarly high levels of IL-12 in vivo. It is notable that the serum IL-12 declined five-fold from day 1 to day 3 whereas the intratumoral IL-12 only began to decline around day 6 . One would expect that changes in the levels of serum IL-12 would parallel those in the tumor, unless structural alterations occur within the tumor during that time period that limit the access of $\mathrm{LL}-12$ to the circulation. IL-12 is known to have angiostatic effects (Voest et al., 1995) and thus the reduced serum levels compared to intratumoral levels at days 3 and 6 may reflect destruction or alteration of the tumor vasculature, preventing $\mathrm{IL}-12$ from leaking into the serum. This is a desirable effect because it would further localize IL-12 expression to the tumor. We are currently investigating the role of antiangiogenesis/vascular destruction in IL-12-mediated killing in our model. Increased $\mathrm{IL}-12$ was also observed within the control tumors treated with $d l 70-3$, consistent with the role IL-12 plays in the antiviral response (Orange and Biron, 1996). Moreover, we have observed antiadenoviral CTL in the tumor draining lymph nodes of mice treated with the control vector alone (J. Bramson, unpublished data). The development of cellular immunity against adenovirus is consistent with the modest antitumoral effects of the control vector seen in previous studies (slightly slower growth as compared to PBS; Addison et al., 1995a).

The induction of IFN- $\gamma$ production by activated NK and T cells is a hallmark of IL-12 stimulation in vitro and in vivo (Seder et al., 1993; Gately et al., 1994; Manetti et al., 1994) and IL-12-mediated tumor regression has been shown to be partially dependent on IFN- $\gamma$ (Nastala et al., 1994; Brunda et al., 1995; Zou et al., 1995). The expression of IFN- $\gamma$ mRNA increases dramatically in tumors and spleens following systemic IL-12 treatment (Zou et al., 1995; Tannenbaum et al., 1996). We have demonstrated that intratumoral IFN- $\gamma$ levels rise very rapidly following intratumoral injection of AdmIL12.1, peaking at 6-9 days, compared to maximal expression of IL-12 at days $1-3$, indicating that the local cytokine environment of the tumor has been altered. Most importantly, cells isolated from the tumor-draining lymph node (TDLN) express IFN- $\gamma$ in culture without additional stimulation, suggesting that these cells had been activated within the tumor as would be expected following exposure to IL-12. These cells may also have been activated within the circulation; however, the ele- 
vation in IFN- $\gamma$ expression as early as day 3 indicates that activation probably occurs within the vicinity of the tumor. Fallarino et al. (1996) demonstrated that high-level production of IFN- $\gamma$ by TDLN cells correlated with tumor rejection in an IL-12-dependent model of tumor rejection. Similarly, we have observed that TDLN cells from AdmIL-12.1-treated animals produce varying levels of INF- $\gamma$, suggesting that IFN$\gamma$ production by TDLN cells in our model may also reflect which tumors will go on to be completely rejected. The effects of intratumoral AdmIL-12.1 injection on IFN- $\gamma$ expression support the hypothesis that Ad-mediated cytokine gene delivery to tumors can affect the local cytokine environment and activate the local effector population with the potential to overcome anergy induced by the tumor.

The results of these initial studies are very promising and we have been experimenting with treatment regimens that may improve the therapeutic value of AdmIL-12.1 treatment. The observation that $>75 \%$ of the tumors initially regress following treatment indicates that we should be able to increase the number of complete regressions with some modifications of the treatment protocol. We have found that the outcome can be improved by combining AdmIL-12.1 with a vector expressing IL2 and that repeated injections may be better than a single injection in certain circumstances (J. Bramson, unpublished data). These studies support the use of AdmIL-12.1 as a safe and efficacious treatment for tumor immunotherapy. The virally expressed cytokine is produced at high levels within the tumor and remains localized to this site, indicating that this approach will likely diminish systemic complications due to excess IL12 in the serum. Thus, continued preclinical experimentation should yield improved treatment strategies that can be applied effectively in a clinical setting.

\section{ACKNOWLEDGMENTS}

We thank Uma Sankar, Duncan Chong, and John Rudy for their expert technical assistance. This work was supported by grants from the National Cancer Institute of Canada (NCIC), the Medical Research Council of Canada (MRC), the Canadian Breast Cancer Initiative, and London Life Insurance. F.L. Graham and W.J. Muller are Terry Fox Research Scientists of the NCIC and J.L. Bramson is supported by a MRC fellowship.

\section{REFERENCES}

ABBAS, A.K., LICHTMAN, A.H., and POBER, J.S., eds. (1991). Cellular and Molecular Immunology. (W.B. Saunders Company, Philadelphia) pp. 335-352.

ADDISON, C.L., BRACIAK, T., RALSTON, R., MULLER, W.J., GAULDIE, J., and GRAHAM, F.L. (1995a). Intratumoral injection of an adenovirus expressing interleukin 2 induces regression and immunity in a murine breast cancer model. Proc. Natl. Acad. Sci. USA 92, 8522-8526.

ADDISON, C.L., GAULDIE, J., MULLER, W.J., and GRAHAM, F.L. (1995b). An adenoviral vector expressing Interleukin-4 modulates tumorigenicity and induces regression in a murine breast cancer model. Int. J. Oncol. 7, 1253-1260.

BETT, A.J., HADDARA, W., PREVEC, L., and GRAHAM, F.L. (1994). An efficient and flexible system for construction of aden- ovirus vectors with insertions or deletions in early regions 1 and 3 . Proc. Natl. Acad. Sci. USA 91, 8802-8806.

BRAMSON, J.L., GRAHAM, F.L., and GAULDIE, J. (1995). The use of adenoviral vectors for gene therapy and gene transfer in vivo. Curr. Opin. Biotechnol. 6, 590-595.

BRAMSON, J., HITT, M., GALLICHAN, W.S., ROSENTHAL, K.L., GAULDIE, J., and GRAHAM, F.L. (1996). Construction of a double recombinant adenovirus vector expressing a heterodimeric cytokine: In vitro and in vivo production of biologically active interleukin-12. Hum. Gene Ther. 7, 333-342.

BRUNDA, M.J., LUISTRO, L., WARRIER, R.R., WRIGHT, R.B., HUBBARD, B.R., MURPHY, M., WOLF, S.F., and GATELY, M.K. (1993). Anti-tumor and anti-metastatic activity of interleukin 12 against murine tumors. J. Exp. Med. 178, 1223-1230.

BRUNDA, M.J., LUISTRO, L., HENDRZAK, J.A., FOUNTOULAKIS, M., GAROTTA, G., and GATELY, M.K. (1995). Role of interferon- $\gamma$ in mediating the antitumor efficacy of interleukin- 12 . J. Immunother. 17, 71-77.

CHENSUE, S.W., RUTH, J.H., WARMINGTON, K., LINCOLN, P., and KUNKEL, S.L. (1995). In vivo regulation of macrophage IL-12 production during type 1 and type 2 cytokine-mediated granuloma formation. J. Immunol. 155, 3546-3551.

COHEN, J. (1995). IL-12 deaths: Explanation and a puzzle. Science 270, 908 .

CORDIER, L., DUFFOUR, M.-T., SABOURIN, J.C., LEE, M.G., CABANNES, J., RAGOT, T., PERRICAUDET, M., and HADDADA, H. (1995). Complete recovery of mice from a pre-established tumor by direct intratumoral delivery of an adenovirus vector harboring the murine IL-12 gene. Gene Ther. 2, 16-21.

FALLARINO, F., UYTTENHOVE, C., BOON, T., and GAJEWSKI, T.F. (1996). Endogenous IL-12 is necessary for rejection of P815 tumor variants in vivo. J. Immunol. 156, 1095-1100.

GATELY, M.K., WARRIER, R.R., HONASOGE, S., CARVAJAL, D.M., FAHERTY, D.A., CONNAUGHTON, S.E., ANDERSON, T.D., SARMIENTO, U., HUBBARD, B.R., and MURPHY, M. (1994). Administration of recombinant IL-12 to normal mice enhances cytolytic lymphocytes activity and induces production of IFN$\gamma$ in vivo. Int. Immunol. 6, 157-167.

GRAHAM, F.L., SMILEY, J., RUSSELL, W.C., and NAIRN, R. (1977). Characteristics of a human cell line transformed by DNA from human adenovirus 5. J. Gen. Virol. 36, 59-72.

GUY, C.T., CARDIFF, R.D., and MULLER, W.J. (1992). Induction of mammary tumors by expression of polyoma middle $\mathrm{T}$ oncogene: A transgenic mouse model for metastatic disease. Mol. Cell Biol. 12, 954-961.

HENDRZAK, J.A., and BRUNDA, M.J. (1995). Biology of disease. Interleukin 12: Biologic activity, therapeutic utility, and role in disease. Lab. Invest. 72, 619-637.

HITT, M., BETT, A.J., PREVEC, L., and GRAHAM, F.L. (1994). Construction and propagation of human adenovirus vectors. In Cell Biology: A Laboratory Handbook. J.E. Celis, ed. (Academic Press, San Diego) pp. 479-490.

MANETTI, R., GEROSA, F., GIUDIZI, M.G., BIAGIOTTI, R., PARRONCHI, P., PICCINNI, M.-P., SAMPOGNARO, S., MAGGI, E., ROMAGNANI, S., and TRINCHIERI, G. (1994). Interleukin 12 induces stable priming for interferon $\gamma$ (IFN- $\gamma$ ) production during differentiation of human T helper (Th) cells and transient IFN- $\gamma$ production in established $\mathrm{Th} 2$ cell clones. J. Exp. Med. 179, 1273-1283.

MEKO, J.B., YIM, J.H., TSUNG, K., and NORTON, J.A. (1995). High cytokine production and effective antitumor activity of a recombinant vaccinia virus encoding murine interleukin 12. Cancer Res. 55, 4765-4770.

NASTALA, C.L., EDINGTON, H.D., MCKINNEY, T.G., TAHARA, H., NALESNIK, M.A., BRUNDA, M.J., GATELY, M.K., WOLF, S.F., SCHREIBER, R.D., STORKUS, W.J., and LOTZE, M.T. 
(1994). Recombinant IL-12 administration induces tumor regression in association with IFN- $\gamma$ production. J. Immunol. 153, 1697-1706.

ORANGE, J.S., and BIRON, C.A. (1996). An absolute and restricted requirement for $\mathrm{IL}-12$ in natural killer cell IFN- $\gamma$ production and antiviral defense: Studies of natural killer and $\mathrm{T}$ cell responses in contrasting viral infections. J. Immunol. 156, 1138-1142.

PARDOLL, D.M. (1995). Paracrine cytokine adjuvants in cancer immunotherapy. Annu. Rev. Immunol. 13, 399-415.

SARMIENTO, U.M., RILEY, J.H., KNAACK, P.A., LIPMAN, J.M., BECKER, J.M., GATELY, M.K., CHIZZONITE, R., and ANDERSON, T.D. (1994). Biologic effects of recombinant human interleukin-12 in squirrel monkeys (Sciureus saimiri). Lab. Invest. 71 , 862-873.

SEDER, R.A., GAZZINELLI, R., SHER, A., and PAUL, W.E. (1993). $\mathrm{IL}-12$ acts directly on $\mathrm{CD} 4+\mathrm{T}$ cells to enhance priming for IFN-g production and diminishes IL-4 inhibition of such priming. Proc. Natl. Acad. Sci. USA 90, 10188-10192.

TANNEBAUM, C.S., WICKER, N., ARMSTRONG, D., TUBBS, R., FINKE, J., BUKOWSKI, R.M., and HAMILTON, T.A. (1996). Cytokine and chemokine expression in tumors of mice receiving systemic therapy with IL-12. J. Immunol 156, 693-699.

TARE, N.S., BOWEN, S., WARRIER, R.W., CARVAJAL, D.M., BENJAMIN, W.R., RILEY, J.H., ANDERSON, T.D., and GATELY, M.K. (1995). Administration of recombinant interleukin-12 to mice suppresses hematopoiesis in the bone marrow but enhances hematopoiesis in the spleen. J. Interferon Cytokine Res. 15, 377-383.

VOEST, E.E., KENYAN, B.M., O'REILLY, M.S., TRUITT, G., D'AMATO, R.J., and FOLKMAN, J. (1995). Inhibition of angiogenesis in vivo by interleukin 12. J. Natl. Cancer Inst. 87, 581-586. YANG, Y., NUNES, F.A., BERENCZSI, K., FURTH, E.F., GONC-
ZOL, E., and WILSON, J.M. (1994). Cellular immunity to viral antigens limits E1-deleted adenoviruses for gene therapy. Proc. Natl. Acad. Sci. USA 91, 4407-4411.

ZITVOGEL, L., TAHARA, H., CAI, Q., STORKUS, W.J., MULLER, G., WOLF, S.F., GATELY, M., ROBBINS, P.D., and LOTZE, M.T. (1994). Construction and characterization of retroviral vectors expressing biologically active human interleukin-12. Hum. Gene Ther. 5, 1493-1506.

ZITVOGEL, L., TAHARA, H., ROBBINS, P.D., STORKUS, W.J., CLARKE, M.R., NALESNIK, M.A., and LOTZE, M.T. (1995). Cancer immunotherapy of established tumors with IL-12: Effective delivery by genetically engineered fibroblasts. J. Immunol. 155, 1393-1403.

ZOU, J.-P., YAMAMOTO, N., FUJI, T., TAKENAKA, H., KOBAYASHI, M., HERRMANN, S.H., WOLF, S.F., FUIIWARA, H., and HAMAOKA, T. (1995). Systemic administration of rll-12 induces complete tumor regression and protective immunity: Response is correlated with a striking reversal of suppressed IFN- $\gamma$ production by anti-tumor $\mathrm{T}$ cells. Int. Immunol. 7, 1135-1145.

Address reprint requests to: Dr. F.L. Graham Departments of Biology and Pathology McMaster University 1280 Main Street West Hamilton, Ontario, Canada L8S 4KI

Received for publication June 28, 1996; accepted after revision August 6, 1996. 